\title{
排便障害の有無からみたRectoceleの検討
}

\author{
日本大学第 1 外科, 同救急医学* \\ 富 田凉一五十嵐誠悟萩 原紀 嗣 \\ 福 澤 正 洋 丹正勝 久*
}

\section{Studies on Rectocele with and without Defecation Disorders}

\author{
Ryouichi TOMITA, Seigo IGARASHI, Noritsugu HAGIWARA, \\ Masahiro FUKUZAWA and Katsuhisa TANJOH
}

First Department of Suxgery, Nihon University School of Medicine

最近 2 年間に経験したrectocele50症例（すべて女性）の内訳は，排便時に残便感，排便困難，慢性便秘などの 有症状症例34例 (24-79歳, 平均55.4歳) と, 無症状 (正常排便) 症例16例 (24-74歳, 平均44.3歳) であり, 画者の臨床的特徵を比較検討した。その結果，1）有症状例の主訴は残便感が最も多かった。2) 排便回数は有 症状例に比較して無症状例では 1 回/日が明らかに多かった。3)排便時怒責を有する例が両者ともに明らかに多 かった。4）経産婦が有症状例では明らかに多く，無症状例でも多かった。5）会陰下垂を伴う例が両者とも最 も多かった。6）大きさは，有症状例では $2 \mathrm{~cm}$ 以上，無症状例では $2 \mathrm{~cm}$ 未満の例が多かった。

索引用語：直腸瘤（Rectocele），臨床的所見 (Clinical findings)

\section{はじめに}

排便注腸造影defecography法が行われるよう になり，直腸の形態学的異常の 1 つである

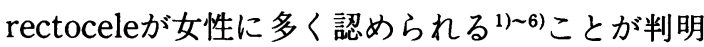
してきた。これまでの欧米を中心とした報告では， 残便感などの排便障害を訴える症例によく認めら れることから，その原因疾患の1つとされてきた。 しかし，最近defecographyが沉用されるようにな ク，なんら症状を有さない例にも多く存在する ${ }^{6)}$ ことが明らかになってきた。そこで，著者らは defecographyにてrectoceleと診断された症例を， 排便時に残便感，排便困難，便秘などの愁訴を有 する症例と正常排便症例の 2 群に分け，それらの 臨床的特徴を比較検討した。

\section{対象および方法}

\section{1. 対象}

1996年 1 月から 1997 年12月までの 2 年間に，当 科外来で経験したrectocele50症例である。これら は全例が女性で, 排便時に何らかの愁訴(残便感, 排便困難, 便秘など) を訴之た有症状症例34例 (年 齢分布24-79歳, 平均55.4歳）と，体表疾患で入 院し本検査に協力してくれた無症状（正常排便） 症例16例（年齢分布24-74歳，平均44.3歳）であ った。

\section{2. 方法}

被検者を左側臥位として，注腸用バリウム 120 $\mathrm{ml}$ に小麦粉 $150 \mathrm{~g}$ をよ擋汼し, 正常便とほぼ同程 度の硬度にし，モノジェクターで直接肛門から注 入した。そして, 透視台に固定した便座に座らせ, 


\section{日本外科系連合学会誌 第 23 卷 6 号}

右側面からレントゲン透視下に安静時, 肛門収縮 時，怒貢時のレントゲン撮影を行った。特に，怒 責時では明確に直腸肛門形態異常が出現した時点 で撮影を行った。そして，得られたフィルムから， 会陰下垂の程度については，恥骨上縁と尾骨下縁 を結ぶ直線と平行な直腸肛門連結部を通過する線 との間に直角に線を引き，その距離を測定し，安 静時に $2 \mathrm{~cm}$ 以上，怒責時に $3 \mathrm{~cm}$ 以上ある場合を， 会陰下垂pelvic floor descent陽性（会陰下垂症候 群）とした。なお，怒責時に肛門管が開かない場 合を恥骨直腸筋弛緩不全，あるいは肛門管収縮時 と同様またはそれ以上に恥骨值腸筋の収縮を認奻 る場合は恥骨直腸筋奇異性収縮としている1147738 が，本論文では両者をまとめて恥骨直腸筋症候群 とした。なお， rectoceleは怒賣時のレントゲン側 面撮影写真で，直腸前壁が瘤状に膣方向に突出子 る像として描出される。したがって, rectoceleの 大きさは，怒責時での肛門管長軸の延長線に rectocele頂点から垂直に引いた線の交差するま での距離とした（Fig.1）。

統計学的解析には, Chi-square testを用い, p< 0.05 を持って有意とした。

\section{結果}

\section{1。有症状例の主訴}

残便感が $52.9 \%(18 / 34)$ と最も多く,ついで便 秘 $47.1 \%(16 / 34) ，$ 排便困難 $41.1 \%(14 / 34)$ ，会 陰部重压感 $5.9 \%$ (2/34)であった(Table. 1$)$ 。

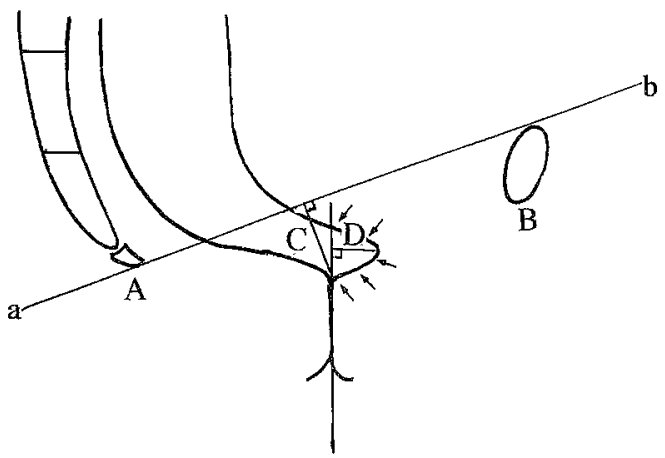

Fig. 1 Anatomic parameters for defecogram A: Coccyx, B:Pubis, C:Perineal descent, D: Length (size) of rectocele, $a b:$ The pubococcygeal line, Arrows: A rectocele

\section{2. 排便習慣}

排便回数については，有症状例では， 1 回/ 2 3 日 $35.3 \%(12 / 34)$ が最も多く,ついで1回/日 と1回/週がそれぞれ $14.7 \%(5 / 34)$ であり，無 症状例では，1回/日62.5\%(10/16) が最も多く， ついで 1 回/ $2-3$ 日 $25.0 \%(4 / 16)$ であった

(Table. 2)。1 回/日の排便回数は, 有症状例が有 意に無症状例より少なかった（ $\mathrm{p}<0.01 ） 。$ 排便時 怒責については，それ有するものは，有症状例 では64.7\%(22/34)，無症状例では25.0\%(4/16) であった (Table. 2)。有症状例では，怒責を認め る例が認めない例より有意に多く $(\mathrm{p}<0.05)$, 無 症状例では，怒責を認めない例が認める例上り有 意に多かった $(\mathrm{p}<0.01)$ 。

\section{3 . 出産の有無}

有症状例では，出産経駧を有する例が70.6\% (24/34）で未産婦例29.4\%（10/34）より有意に 多かった $(\mathrm{p}<0.01)$ 。無症状例でも，出産経験を 有する例が $62.5 \%(10 / 16)$ で未産婦例 $37.5 \%$ (6/ 16）より多かった（Table.2）。

\section{4. 怒責時defecography所見}

rectocele以外の直腸壁抒よび骨盤底筋群異常 所見の有無については，有症状例では，直腸重責 を伴う例が $26.5 \%(9 / 34)$ と最も多く，ついで会 㓌下瑟を伴う例の $23.5 \%$ (8/34)であった。無症 状例でも，直腸重責を伴う例が $31.3 \%(5 / 16)$ と

Table. 1 The chief symptom of patients with rectocle who have defecation disorders.

\begin{tabular}{lr}
\hline Feeling of incomplete evacuation & $52.9 \%(18 / 34)$ \\
Constipation & $47.1 \%(16 / 34)$ \\
Difficulty in defecation & $41.1 \%(14 / 34)$ \\
Perianal discomfort & $5.9 \%(2 / 34)$ \\
Others & $8.8 \%(3 / 34)$ \\
\hline
\end{tabular}

Table. 2 Patients characteristics.

\begin{tabular}{|c|c|c|}
\hline Frequency of bowel habit & Patients with symptome & Patients without symptom \\
\hline $2-3 /$ day & $11.8 \%(4 / 34)$ & $12.5 \%(2 / 16)$ \\
\hline t/day & $14.7 \%(5 / 34)$ & $62.5 \%(10 / 16)$ \\
\hline 1/2-3days & $35.3 \%(12 / 34)$ & $25.0 \%(4 / 16)$ \\
\hline l/wreek & $20.6 \%(7 / 34)$ & $0 \%(0 / 16)$ \\
\hline $\mathrm{I} / 2$ weeks & $14.7 \%(5 / 34)$ & $0 \%(0 / 16)$ \\
\hline 1/month & $2.9 \%(1 / 34)$ & $0 \%(0 / 16)$ \\
\hline \multicolumn{3}{|l|}{ Defecation with straingng } \\
\hline$(-)$ & $35.3 \%(12 / 34) 7$ & $75.0 \%(12 / 16)$ \\
\hline$(t)$ & $64.7 \%(22 / 34)]^{*}$ & $25.0 \%(4 / 16)$ \\
\hline \multicolumn{3}{|l|}{ Delivery } \\
\hline$(-)$ & $29.4 \%(10 / 34) \sqsupset *$ & $37.5 \%(6 / 16)$ \\
\hline$(+)$ & $70.6 \%(24 / 34)]^{*}$ & $62.5 \%(10 / 16)$ \\
\hline
\end{tabular}


最も多く，ついで会陰下垂を伴う例が $25.0 \%$ ( 4 / 16）\%であった。会陰下垂を伴う例が有症状例で は44.1 (15/34), 無症状例では37.5\% (6/16) と 多かった (Table. 3 )。

\section{5. rectoceleの大きさ}

有症状例では $1.5-5.5 \mathrm{~cm}$ (平均 $2.8 \pm 0.1 \mathrm{~cm}$ ), 無症状例では0.5-2.5cm (平均 $1.5 \pm 0.7 \mathrm{~cm}$ ) であ $\eta$ ，有意に前者が後者に比較して大きかった $(\mathrm{p}<$ 0.001) (Table. 4 )。

\section{考察}

直腸壁の形態学的異常の 1 つである rectocele

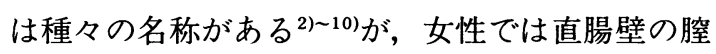
側が, 男性では膀胱側がポケット状に突き出るこ とから直腸瘤とも呼ぶこともある。しかし, 一般 的な呼び名でないため, 本論文ではrectoceleとし て述べることにする。性別は女性がほとんどであ ク，男性は稀であり $0-9.3 \%$ 報告 ${ }^{2) ~ 8) さ れ て い ~}$ る。年齢分布は 20 歳代の若年者から 80 歳代の高齢 者まで幅広くみられ，40-50歳代（特に50歳代） にピークを認める。著者らの症例でも, 症状の有 無に関係なく，全例が女性であり $24-79$ 歳と広く 分布し, 特に 40,50 歳代が多く, 従来の報告と同 様の傾向を示した。

病因については，加齢，排便障害や不良な排便 習慣による怒責, 出産, 閉経後のエストロゲン分 泌低下などにより骨盤底・会陰部組織が脆弱にな

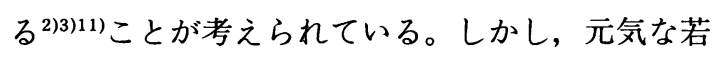
年者も認めること，また排便時怒責のない例にも 認められること, 未産婦にも認められること, な どから必ずしもこれらの要因 1 つのみで説明する

Table. 3 Defecographic findings.

\begin{tabular}{llc}
\hline & Patients with symptom & Patients without symptom \\
\hline RI+rectocele & $26.5 \%(9 / 34)$ & $31.3 \%(5 / 16)$ \\
PD+ rectocele & $23.5 \%(8 / 34)$ & $25.0 \%(4 / 16)$ \\
$R I+P D+$ rectocele & $20.6 \%(7 / 34)$ & $12.5 \%(2 / 16)$ \\
Rectocele & $14.7 \%(5 / 34)$ & $18.8 \%(3 / 16)$ \\
PS + rectocele & $14.7 \%(5 / 34)$ & $12.5 \%(2 / 16)$ \\
\hline & Rectal intussusception; RI, Perineal descent; PD, Puborectalis syndrome; PS
\end{tabular}

Table. 4 The size of rectocele.

\begin{tabular}{rr}
\hline Patients with symptom & Patients without symptom \\
\hline $2.8 \pm 1.0 \mathrm{~cm}$ & $* \quad 1.5 \pm 0.7 \mathrm{~cm}$ \\
\hline$* \mathrm{p}<0.001$
\end{tabular}

ことは無理なようである。著者らの症例も, 症状 の有無に関係なく，若年者から高齢者まで幅広い 年齢層に分布し, 未産婦にも存在し, 排便障害の 有無に関係なく, 排便時怒責のない例にも認める ことより，必ずしも 1 つの因子で発生するのでは なく, 幾つかの因子が組み合わされ形成され る9) 12) と考之られた。なお, 有症状例では無症状例 に比較して排便時に怒責を有する例が明らかに多 かった。このことは下記で述べるが, 便秘や排便 困難を訴える例が有症状例に多かったことによる と考えている。

症状については, 残便感, 便秘, 排便困難, 肛

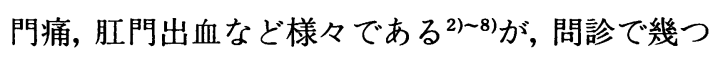
かの特徵的事柄がある。すなわち, 肛門の周りを 圧迫したり，臸に指を入れたり，浣腸や下剤など 使用することにより排便, 便は降りてきているが 肛門から出ない, 出口が塞がれている感じがする, 肛門に袋が有る, 常に下方に圧迫感がある, な ど213)である。しかし, 排便障害の全く認めない症

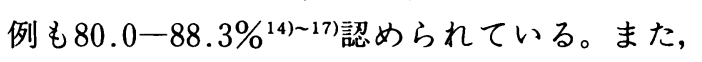
rectoceleの大きさは症状に関係しない5), $2 \mathrm{~cm}$ 以 下では無症状がほとんどである ${ }^{13) 14)}, 2-3 \mathrm{~cm}$ 以 上では症状を有する ${ }^{13) 18)}$ ，とする種々の報告があ る。 $2 \mathrm{~cm}$ 以上の大きいrectoceleは便秘例に多く, そのなかに排便後も便が残り残便感をもたらす18) という。著者らの症例では, 有症状例は $68 \%(34)$ 50）であり，これらの全てが排便に付随した症状 を認め, なかでも残便感を最も多く訴えた。なお, 問診時に前述した事柄を話したところ，3 例が排 便時に臸内に， 1 例が直腸内に指を入れ排便をし ていたことが判明し, 問診の重要性があらためて 確認された。大きさについては, 有症状例では 2 cm以上がほとんどで無症状例（1 cm以下が多く を占めた）より明らかに大きい症例が多かった。 よって, 無症状例でも大きさが $2 \mathrm{~cm}$ 以上の例では 将来排便異常を示す可能性があると思われ経過観 察の必要性を考えている。

診断については, 問診で排便異常（前述した事 柄）に注意を払うことが大事であり，直腸指診で は肛門より直腸内前方から胵に向かい袋状に突出 認めること, defecographyの怒責時で直腸前壁が 腔側に袋状に突き出ていること, などで容易に診 
断される ${ }^{1) \sim 8)}$, 付随的所見として, 安静時と怒責時 の会陰下垂程度は健常人より高度であるが多く, 直腸重責や恥骨直腸筋症候群などもよく認められ

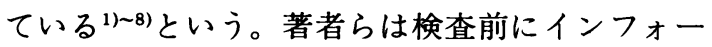
ムドコンセントを十分行い, 被検者からdefecographyを施行する際の協力を得ること, また，検 査時に十分怒責をさせバリウムを排泄させること でrectocele, 直腸重責, 会陰下垂症候群などの診 断率を高めることができると考えている。特に, 恥骨直腸筋症候群は, 被検者に慣れないスタイル で排便動作をさせることで偽陽性が多い15) といわ れている。恥骨直腸筋症候群の併存は著者らの検 討では併存は比較的少なかった。なお, 朝比奈7は 会陰下垂（骨盤底筋群が脆弱）では怒責とともに 骨盤底筋群が過伸展となるため十分な腹圧がかか らず排便困難を来すとしている。著者らの症例も， 会陰下垂は症状の有無に関係なく認められたが, 有症状例が無症状例よりその頻度は高かった。

治療については, 有症状例ではまず保存的治療 が行われ，便通を整えることが第一にあり，薬物 療法 (緩下剂, 整腸剂), 食事療法 (高繊維食), 排便習慣改善指導などを行う ${ }^{2) 3}$ 。しかし，保存的 療法でよくなる例は約 $20 \%$ と少ない。そこで，無 効例では外科的治療が選択され, 経直腸的あるい は経膣的に直腸前壁縫縮術が行われるが, 両者の 術後成績に差は無い233)ようである。著者らの症例 では, 保存的療法を約 1 力月行ったところ, 症状 の消失した 6 例と改善した 2 例を経験した。保存 的療法の有効率は $23.5 \%(8 / 34)$ であった。しか し, 残りの症例は無効であり, 残便感が強く手術 を希望する者が 2 例おり, 近く手術する予定でい る。なお, rectoceleの大きさが $2 \mathrm{~cm}$ 以上では手術 適応となるとする報告 ${ }^{17)}$ もる。Karlbomら ${ }^{17)}$ は, rectoceleの縫縮術後の大きさが平均 $1.9 \mathrm{~cm}$ 以上 の群では症状の改善がなく, $0.7 \mathrm{~cm}$ だと改善した と報告している。著者らの症例では, 保存的療法 が無効であった例は全例が $2 \mathrm{~cm}$ 以上であった。

\section{結語}

defecographyはrectoceleの診断に有用で, 確実 な治療を行うに際し，日常診療に応用されるべき 検査法である。また無症状例では大きさが $2 \mathrm{~cm}$ 以
下の例が殆どであるが，大きさが増せば将来，直 腸骨盤底筋群の解剖学的変化がより増して, 残便 感や便秘などの症状を訴之る可能性もあり, 十分 に注意して経過を観察すべきである。

\section{参考文献}

1) Bartolo D CC, Read NW, Jarratt JA, et al: Differences in anal sphincter function and clinical presentation in patients with pelvic floor descent. Gastroenterology $83: 68-75,1983$

2) 高野正博, 藤好建史, 高木幸一他：Rectocele(直 腸臸壁弛緩症）39例の分析. 日本大腸肛門病会誌 $41: 796-802,1988$

3）東 光邦, 隅越幸男, 岩垂純一他：Rectoceleの診 断とその治療. 日本大腸肛門病会誌 $43 ： 1094-$ 1097, 1990

4）朴哲在, 季 基周, 隅越幸男 : 排便障害診断 : Defecography，日本大腸肛門病会誌43：606612, 1990

5）吉岡和彦, 早田和訓, 松井陽一他：Rectoceleの生 理学的および解剖学的検討. 日本大腸肛門病会誌 $44: 1025-1029,1991$

6）天野信一：直腸瘤の診断一直腸指診から一. Therapeutic Res12：115-118, 1991

7）朝比奈完：Videodefecographyによる排便障害 の形態学的研究. 日本大腸肛門病会誌 $47: 381$ 392, 1994

8）河一京：直腸肛門内圧同調 Videodefecographyによる排便機能障害の検討一Rectoceleを中 心に. 日本大腸肛門病会誌 $48 ： 289-300,1995$

9）富田凉一, 五十嵐誠悟, 萩原紀嗣他：Rectoceleの 診断とその臨床的特徵について. 日外科系連会誌 $22: 886-889,1997$

10）富田凉一：大腸の機能性疾患. Medical Postgraduates35:64-74, 1997

11) Mellgren A, Johansson $C$, Dolk A, et al. : Enterocele demonstrated by defaecography is associated with other prlvic floor disorders. Int $\mathrm{J}$ Colorect Dis $9: 121-124,1994$

12）富田凉一, 五十嵐誠悟, 萩原紀嗣他：直腸内圧力 らみたRectoceleの病態生理学的検討。 日本大腸 肛門病会誌 $51 ： 101-108,1998$

13) Halligan S, Bartram CI. : Is digitation associat- 
ed with proctographic abnormality? Int J Colorect Dis $11: 167-171,1996$

14) Shorvon PJ, McHung S, Diamant NE, et al. : Defecography in normal volunteers: results and implications. Gut $30: 1737-1749,1989$

15) Ting KH, Mangel E, Eibl-Eibesfeldt B, et al. : Is the volume retained after defecation a valuable parameter at defecography? Dis Colon Rectum 35 : 762-767, 1992

16) Mellgren $A$, Bremmer $S$, Johansson $C$, et al.:
Defecography-Results of investigation in 2816 patients. Dis Colon Rectum 3 : 1133-1141, 1994

17) Karlbom U, Graf W, Nilsson S, et al.: Does surgical repair of rectocele improve rectal emptying? Dis Colon Rectum $39: 1296-1302$, 1996

18) Siproudhis L, Ropert A, Lucas J, et al : Defecatory disorders, anorectal and pelvic floor dysfunction. Int $\mathrm{J}$ Colorect Dis $7: 102-$ 107, 1992 